\title{
Predicted sub-populations in a marine shrimp proteome as revealed by combined EST and cDNA data from multiple Penaeus species
}

Pimlapas Leekitcharoenphon ${ }^{1}$, Udon Taweemuang ${ }^{1}$, Prasit Palittapongarnpim², ${ }^{2,}$ Rattanawadee Kotewong ${ }^{4}$, Thararat Supasiri ${ }^{4}$, Burachai Sonthayanon ${ }^{1,2^{*}}$

\begin{abstract}
Background: Many species of marine shrimp in the Family Penaeidae, viz. Penaeus (Litopenaeus) vannamei, Penaeus monodon, Penaeus (Fenneropenaeus) chinensis, and Penaeus (Marsupenaeus) japonicus, are animals of economic importance in the aquaculture industry. Yet information about their DNA and protein sequences is lacking. In order to predict their collective proteome, we combined over 270,000 available EST and cDNA sequences from the 4 shrimp species with all protein sequences of Drosophila melanogaster and Caenorhabditis elegans. EST data from 4 other crustaceans, the crab Carcinus maenas, the lobster Homarus americanus (Decapoda), the water flea Daphnia pulex, and the brine shrimp Artemia franciscana were also used.
\end{abstract}

Findings: Similarity searches from EST collections of the 4 shrimp species matched $64 \%$ of the protein sequences of the fruit fly, but only $45 \%$ of nematode proteins, indicating that the shrimp proteome content is more similar to that of an insect than a nematode. Combined results with 4 additional non-shrimp crustaceans increased matching to $78 \%$ of fruit fly and $56 \%$ of nematode proteins, suggesting that present shrimp EST collections still lack sequences for many conserved crustacean proteins. Analysis of matching data revealed the presence of 4 EST groups from shrimp, namely sequences for proteins that are both fruit fly-like and nematode-like, fruit fly-like only, nematode-like only, and non-matching. Gene ontology profiles of proteins for the 3 matching EST groups were analyzed. For non-matching ESTs, a small fraction matched protein sequences from other species in the UniProt database, including other crustacean-specific proteins.

Conclusions: Shrimp ESTs indicated that the shrimp proteome is comprised of sub-populations of proteins similar to those common to both insect and nematode models, those present specifically in either model, or neither. Combining small EST collections from related species to compensate for their small size allowed prediction of conserved expressed protein components encoded by their uncharacterized genomes. The organized data should be useful for transferring annotation data from model species into shrimp data and for further studies on shrimp proteins with particular functions or groups.

\section{Findings}

\section{Background}

Marine shrimp (order Decapoda, family Penaeidae) are crustaceans of high economic importance, notably the Pacific whiteleg shrimp Penaeus (Litopenaeus) vannamei and the giant tiger shrimp Penaeus (Penaeus) monodon,

\footnotetext{
* Correspondence: burachais@gmail.com

${ }^{1}$ Center of Excellence for Shrimp Molecular Biology and Biotechnology (CENTEX Shrimp), Faculty of Science, Mahidol University, Rama VI Road, Bangkok 10400, Thailand

Full list of author information is available at the end of the article
}

that are prominent species in the shrimp aquaculture industry of several countries in Asia Pacific and the Americas [1]. Other species raised include Chinese shrimp Penaeus (Fenneropenaeus) chinensis and Kuruma shrimp Penaeus (Marsupenaeus) japonicus [2]. Despite the multibillion dollar size of the industry for each country, molecular studies at the nucleotide and protein sequence levels of marine Penaeid shrimp and other Decapod crustaceans are still considered inadequate for investigating numerous farm level problems related to viral and bacterial pathogenesis. Relatively few DNA and

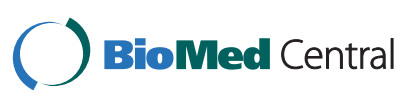


protein sequence entries from true marine shrimp and decapods are present in sequence databases such as GenBank when compared to those from insects and other groups of animals [3]. As of today, no complete decapod crustacean genome sequence has been published, although the genome sequencing project of a copepod crustacean, Daphnia pulex, is complete [4-6]. The majority of crustacean sequences available in primary sequence databases are in small collections as single-pass partial cDNA sequences known as expressed sequence tags or ESTs accessible via GenBank's dbEST database as well as via species-specific EST databases [4,7-9]. However, a number of insect genome sequences from the same Arthropoda phylum have been published and released such as those of Drosophila melanogaster [10], Anopheles gambiae [11], Aedes aegypti [12], and Tribolium castaneum [13]. Genomes of lower eukaryotes that have been characterized include those of Caenorhabditis elegans [14], Caenorhabditis briggsae [15], and Strongylocentrotus purpuratus [16]. Among these, the best studied invertebrate models are $D$. melanogaster and C. elegans.

Full-length and partial cDNA sequences have provided useful snapshots of the protein-coding regions of genomes [17]. However, the number of crustacean full length or partial cDNA sequences in GenBank are in the lower hundred range. Work on shrimp cDNA libraries to generate ESTs have led to characterization of a number of protein coding sequences from isolated full-length cDNA clones [18-22]. Despite the lack of a sufficient number of full length cDNAs, there are small sets of released EST data from a number of species available from public databases. Of interest to the aquaculture industry are studies conducted on P. monodon, $P$. vannamei, $P$. chinensis, and $P$. japonicus, the former two having sizable collections of EST sequences $[8,9,23,24]$. Publications about ESTs often mention a selection of their sequences that have similarity to known entries from other species in databases. However, the coverage of genome-wide proteomes are often not reported. Yet the issue is of interest for researchers and research managers since it could signify how much more effort should be given to generate additional diverse EST + cDNA data to ensure that they cover all the proteins that might be useful for biotechnology applications.

Genome-wide proteome content provides useful information for delimitation of biochemical functions to be expected in cells from a given living species. To predict the scope of a proteome, a comprehensive collection of cDNAs is generally required. Unfortunately, the existing cDNA and EST collections from each shrimp species are small, so the scope of the shrimp proteome has not been previously addressed. For the two prominent aquaculture species, $P$. vannamei and $P$. monodon, there are only around 160,000 and 97,000 ESTs, respectively. For 2 other lesser cultured species, P. chinensis and P. japonicus, there are around 10,000 and 3,000 ESTs, respectively. To study the scope of the expressed shrimp proteome, we decided to overcome the shortcoming of small EST collections by combining data from the species with sizable collections and to analyze them as a representative model for the Penaeid shrimp group. By comparing them with whole-genome protein sequences from the two well-studied models in the phyla Arthropoda and Nematoda using the BLAST program [25], we found evidence that the collective shrimp or crustacean proteome is more similar to the proteome of an insect than a nematode. Almost ten thousand proteins of D. melanogaster and C. elegans were predicted to have similar proteins in shrimp and Decapods. We also estimated the extent of shortcoming in shrimp EST collections. More importantly, we predicted that the shrimp proteome could be subdivided into groups, one that has protein sequences similar to those found in both the insect and nematode, one that has protein sequences similar to only the insect proteins, one that has protein sequences similar to only the nematode proteins, and one that has protein sequences similar to neither of these models. This unexpected new finding is noteworthy for people working with crustacean genes or genomes. Lastly, features of the predicted protein coding sequences in matching EST groups were analyzed for their functional profiles by GO analysis [26-28].

\section{Methods}

EST data were obtained mainly from GenBank dbEST (downloaded on August 10, 2009) [3,7]. For P. monodon, data sets from Penaeus monodon EST project database were also added [8,9]. Available cDNA sequences from GenBank for P. monodon (415 sequences) and P. vannamei (339 sequences, accessed October 29, 2009) were added to the EST data for each species. The shrimp species analyzed included the giant tiger shrimp $P$. monodon $(97,805$ ESTs + 415 cDNAs $)$, the Pacific whiteleg shrimp P. vannamei (160,381 ESTs + 339 cDNAs), fleshy shrimp $P$. chinensis (10,446 ESTs), and Kuruma shrimp P. japonicus (3,152 ESTs), totaling 272,538 ESTs for the 4 shrimp species. Other Penaeid shrimp species having small numbers of EST and cDNA were not included in this study. Other Decapod sequences from dbEST were from the Atlantic lobster Homarus americanus $(29,558$ ESTs), and the littoral crab Carcinus maenas $(15,558$ ESTs). Total ESTs for all 6 Decapoda species were 317,654 entries. Non-Decapod primitive crustaceans included were brine shrimp Artemia franciscana (37,487 ESTs), and the water flea Daphnia pulex $(165,917$ ESTs). Protein coding sequences from the fruit 
fly D. melanogaster $(20,815$ sequences, version 5.4$)$ and the nematode $C$. elegans (27,258 sequences, data version 190) were obtained from Ensemble database [29]. Predicted protein sequence set for $D$. pulex was obtained from wFleaBase [4]. Protein data of all living species were obtained from UniProt (accessed October 30, 2009), comprising 509,019 protein sequences [30].

BLASTX and TBLASTN programs (version 2.2.18) were performed in a Linux computational cluster at the National Center for Genetic Engineering and Biotechnology (BIOTEC), Thailand, with a cut-off $E$ value set at $10^{-4}$. Queries between DNA sequences from each crustacean species and protein sequences from each model species were computed separately. Outputs from BLAST analyses were parsed by Perl scripts using BioPerl code modules [31]. Grouping of EST data was performed using a Python script to extract just best-hit entries for each query from BLASTX and TBLASTN results. GO mappings were conducted using a perl script to traverse through graph structure of ontology data using a publicly available go-perl module and existing full GO annotation data from FlyBase and WormBase [27,28].

\section{Results and Discussion}

The scope of the shrimp expressed proteome was determined by running BLASTX and TBLASTN $\left(\mathrm{E}<10^{-4}\right)$ between the DNA sequence collection from each shrimp species and the protein sequences from each model species, D. melanogaster, and C. elegans. Matching results for each shrimp species returned by the two programs were combined. Comparison of those with proteins from a crustacean model, Daphnia pulex, was also conducted as a control. Figure 1 shows percentages of matchings between crustacean EST collections and protein sequences from the model species. For EST + cDNA from both of the major aquaculture species, P. monodon or P. vannamei, 36-39\% of ESTs gave significant similarity to reference protein sequences, constituting $50-58 \%$ of all the proteins in the fruit fly (Figure $1 \mathrm{~A}$, data sets 1-2). When shrimp ESTs were compared to proteins from the nematode, $23-30 \%$ of the ESTs from either $P$. monodon or P. vannamei gave significant matchings with only $33-40 \%$ of nematode proteins (Figure $1 \mathrm{~B}$, data sets 1-2). When data from the 2 shrimp species were combined, the percentage of protein similarity with the fruit fly and nematode proteins rose significantly to $63 \%$ and $45 \%$, respectively (Figure 1A, B, data set 3, pink and green bars). When smaller sets of EST data from the 2 other lesser farmed shrimp species, $P$. japonicus and $P$. chinensis were added to create a 4 shrimp species set, the percentage of protein matchings with those of fruit fly and nematode rose slightly to $64 \%$ and $45 \%$, respectively (Figure $1 \mathrm{~A}, \mathrm{~B}$, data set 4 , pink and green bars). As farmed Penaeid shrimp are decapods, addition of EST data from 2 more decapod species (Homarus americanus and Carcinus maenas) to constitute a 6-species Decapod data set, the percentage of similarity with fruit fly and the nematode proteins rose to $72 \%$ and $52 \%$, respectively (Figure $1 \mathrm{~A}, \mathrm{~B}$, data set 6, pink and green bars). If EST data from 2 small crustacean species, Daphnia pulex and brine shrimp Artemia franciscana were also added to generate an 8 species crustacean EST data set, the percentages of similarity matchings increased to $78 \%$ and $56 \%$ of fruit fly and nematode proteins, respectively (Figure 1A, B, data set 7 , pink and green bars). These results showed a trend that the matching sequences of shrimp and other crustaceans are more similar to proteome sequences of the fruit fly than nematode. This result was not surprising, given that crustaceans are classified in the same phylum Arthropoda as insects. Nevertheless, this result is special since we used a trend of genome-wide expressed sequence data, not just few markers, to support the notion of more similarity between crustaceans and insects than crustaceans and nematodes. The result also suggested that the majority of the fruit fly proteins (64-78\%) might have similar proteins in shrimp and crustaceans (Figure 1A, data sets 4-7, pink bars). This implied that a protein set from the fruit fly, if selected for those with matching ESTs from shrimp and crustaceans, might be used as a Systems Biology data model for shrimp and crustaceans.

We then proceeded to determine if existing shrimp EST collections had covered all the expressed proteome or not. If ESTs from only 4 shrimp were grouped, they gave a $64 \%$ match with fruit fly protein sequences. However, when EST data from all 8 crustaceans were grouped, they gave $78 \%$ matching. The $14 \%$ difference suggested that the existing EST data from the 4 Penaeus species still lack sequences of around $14 \%$ of the conserved pan-crustacean proteins. If the percent of fruit fly protein hits by ESTs from 6 species of decapods (72\%) is considered, the difference is $8 \%$ (Figure $1 \mathrm{~A}$, data sets 4,6). Again, this suggested that the current set of EST data from economic shrimp lacks representation from around $8 \%$ of conserved decapod proteins, not taking into account possible sequence divergences among thousands of shrimp and decapod species. As a control for comparison, the EST set from the model crustacean, Daphnia pulex, which has the largest EST collection among crustaceans in dbEST, gave $71 \%$ similarity to fruit fly proteins (Figure 1A, data set 8 , pink bar). When EST data from Artemia were added to the Daphnia data set, similarity rose slightly to $73 \%$ (Figure $1 \mathrm{~A}$, data set 10 , pink bar), still lower than the $78 \%$ from the result of 8 combined crustacean species (data set 7 , pink bar), yet about the same value of $72 \%$ obtained using the combined data from 6 decapods. So, $8 \%$ lack of 

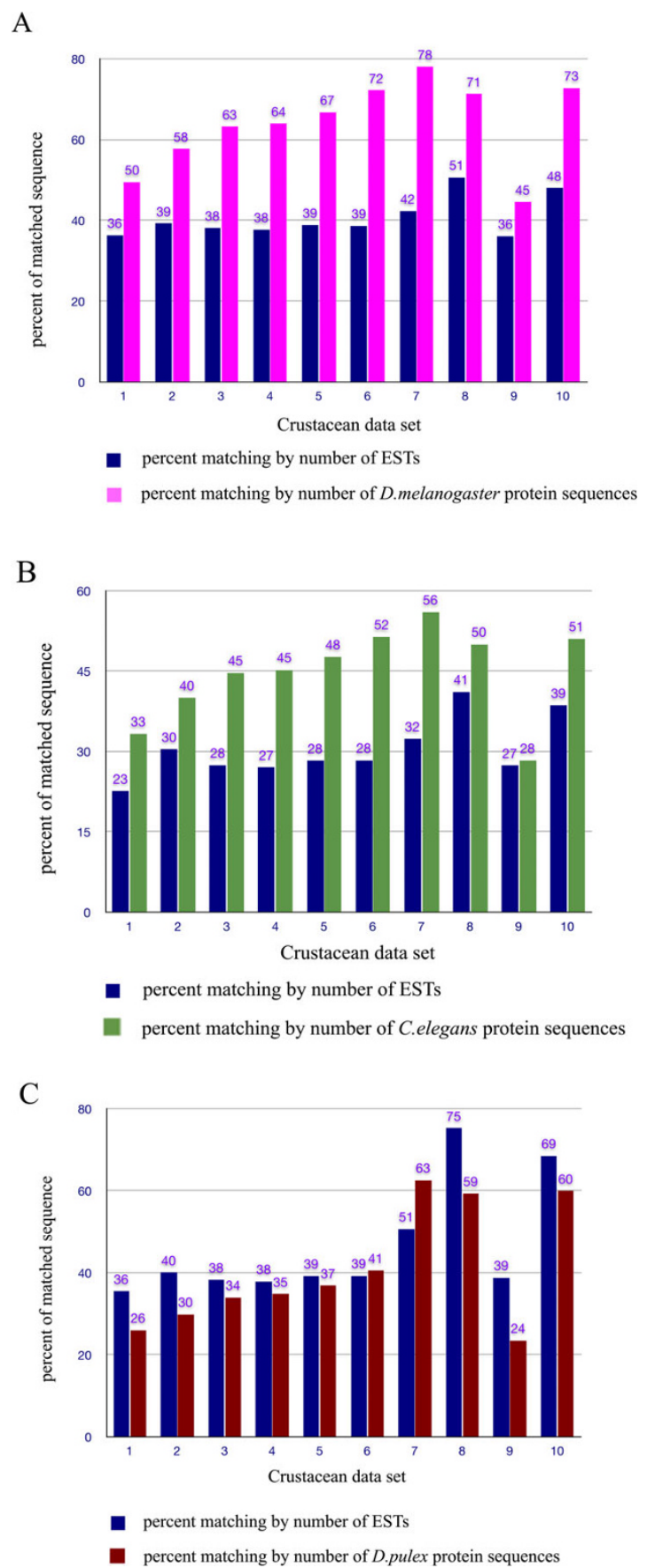

Figure 1 Matching between shrimp and crustacean ESTs and proteins from model species. Matching percentages obtained from BLASTX and TBLASTN results are shown relative to the total number of crustacean EST sequences in each set (dark blue bars) or to the total number of protein sequences in a model species (pink bars for D. melanogaster, green bars for C. elegans, dark red bars for Daphnia pulex). Data sets were either for single crustacean species or multiple species as follows:- set $1: P$. monodon (total $=98,220$ ESTs + CDNAs). set $2: P$. vannamei (total $=$ 160,720 ESTs + CDNAs). set $3:$. P. monodon and P. vannamei (total $=258,940$ ESTs + CDNAs). set $4: P$. monodon, $P$. vannamei, $P$. chinensis and $P$. japonicus (total $=272,538$ sequences). set $5: 4$ true shrimp species +1 decapod species, $P$. monodon, $P$. vannamei, $P$. chinensis, $P$. japonicus and C. maenas (total $=288,096$ sequences). set $6: 4$ true shrimp species +2 decapod species, P. monodon, $P$. vannamei, P. chinensis, P. japonicus, C. maenas and $H$. americanus (total $=317,654$ sequences). set $7: 4$ true shrimp species +4 other crustacean species, $P$. monodon, $P$. vannamei, P. chinensis, P. japonicus, C. maenas, H. americanus, A. franciscana and D. pulex (total $=521,058$ sequences). set $8:$ D. pulex (total $=165,917$ ESTs). set 9 : A. franciscana (total $=37,487$ ESTs). set $10:$ D. pulex and A. franciscana (total $=203,404$ ESTs). (A) Matching when comparing with 20,815 protein sequences of $D$. melanogaster. (B) Matching when comparing with 27,258 protein sequences of $C$. elegans. (C) Matching when comparing with 37,466 protein sequences of $D$. pulex. 
representation of conserved proteins in the shrimp EST and cDNA collections seems to be a good approximation.

We were also interested in comparing shrimp ESTs with sequences of predicted proteins from the crustacean model, D. pulex from wFleaBase (Figure $1 C$ ). The percent matching by number of EST from each shrimp species or in combination with decapod ESTs were similar to the respective matching percentages with fruit fly proteins (Figure 1C, dark blue bars for data sets 1-6). However, the matching percentages by the number of predicted proteins in D. pulex were lower (Figure 1C, red bars, data sets 1-6) than those in D. melanogaster, possibly due to the much higher number of predicted protein sequences in this species $(37,466$ sequences) compared to fruit fly $(20,815$ sequences) and worm proteins $(27,258$ sequences). The higher percentage of matchings for nucleotides from either $D$. pulex or $A$. franciscana, or from both, to predicted protein sequences from $D$. pulex (as observed in lanes $8,9,10$ ) may be due to the presence of more redundant ESTs from the two collections. EST Data combined from 6 decapod species gave only $41 \%$ matching by number of Daphnia proteins. Interestingly, ESTs from D. pulex had only $75 \%$ matching by ESTs, and $59 \%$ matching by predicted Daphnia proteins (Figure 1C, data set 8, blue and red bars). This suggested that there was a practical upper limit of matching between an EST data set and genome-wide predicted protein sequences, even for data from the same species. Therefore, the matching of combined ESTs from 8 crustacean species to $78 \%(16,268$ proteins) of fruit fly proteins should be considered very high. The analysis showed that this approach of using combined EST + cDNA data from multiple related species to compensate for the lack of cloned low-abundant transcripts, especially from species with small EST collections in sequence databases, provided useful global information on the evolutionarily-conserved proteome content of a group of related species.

With the current focus on shrimp species of economic importance, we further analyzed ESTs from only the 4 Penaeid shrimp species based on the presence or absence of best hit proteins with model species in order to predict the scope of the proteome of shrimp. As shown in the Venn's diagram of Figure 2, 61\% of the combined ESTs from 4 shrimp species did not match fruit fly or nematode protein sequences. Around 38\% $(12 \%+26 \%)$ of the shrimp ESTs had best similarity matchings with fruit fly protein sequences and just $27 \%$ $(26 \%+1 \%)$ with nematode protein sequences. The matched EST population from shrimp could thus be divided into 3 groups, namely group 1 ESTs (26\%) with matching proteins present in both the fruit fly and nematode [Additional file 1]; group 2 ESTs (12\%),

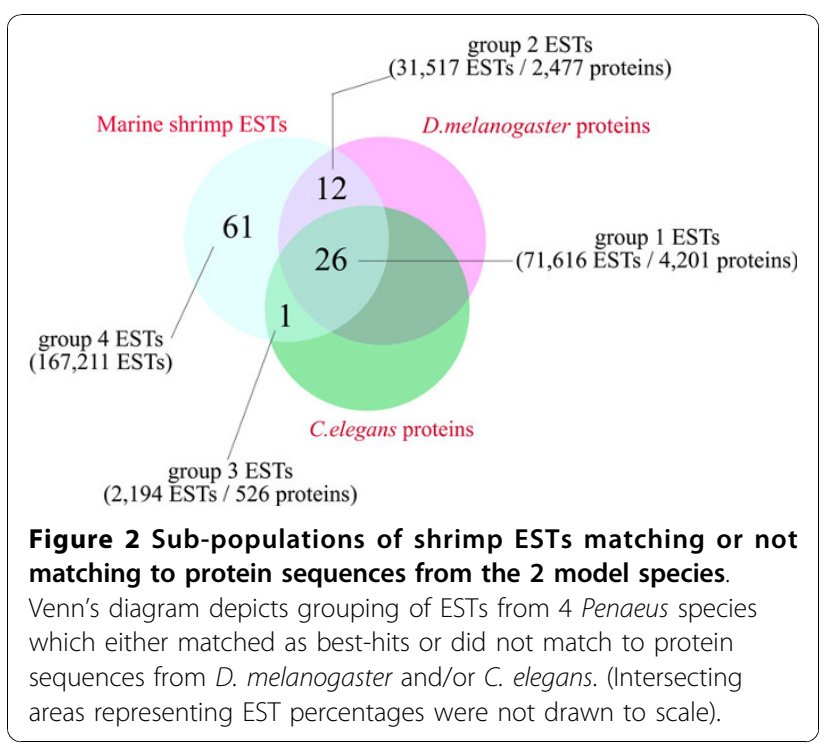

present in the fruit fly but not the nematode [Additional file 2]; and group 3 ESTs (1\%) present in the nematode but not the fruit fly [Additional file 3]. However, these percentage values shown by EST numbers for each group need to be interpreted with care since EST records in databases are known to be redundant. This is because the EST records come from sequencing of randomly picked clones from various types of cDNA libraries. Assuming that their discovery frequency depends approximately on the relative abundance of each mRNA species in cell sources, one would expect to have more redundant ESTs from highly expressed transcripts than from lowly or conditionally expressed transcripts. Therefore, more useful information would be the corresponding number of best matched proteins predicted from the model species that corresponded to each EST group. The best-matched fruit fly-like and nematode-like proteins for group 1 ESTs of shrimp were equivalent to 4,201 fruit fly proteins, equivalent to around $20.2 \%$ of fruit fly protein sequences, and the best matched fruit fly-like only proteins for group 2 ESTs were equivalent to 2,477 fruit fly proteins (11.9\% of fruit fly protein sequences). The best matched nematode-like only proteins for group 3 ESTs of shrimp were equivalent to $526(1.9 \%)$ of nematode proteins. The total number of proteins from the 2 model species matched by the currently-available shrimp ESTs were equivalent to 7,204 (fruit fly + worm) proteins. If data from 2 additional decapod species were added, the 3 matching groups increased to 9,621 proteins (data not shown). This also implied that, compared to EST data from 2 Decapoda species, the current collection of shrimp ESTs still does not account for around 2,400 conserved Decapod proteins. With newly improved sequencing technology, the limited number of ESTs for P. monodon and 
P. vannamei will hopefully be resolved in the near future. In spite of the current shortcomings of shrimp ESTs, the results suggested that protein sequences from D. melanogaster and C. elegans which matched to the 3 EST groups are both needed to build a proteome model in shrimp and decapods. We also envisage that the 3 groups of shrimp and decapod ESTs that matched Drosophila and Caenorhabditis proteins will serve as a useful set of sequences for further research in transcriptomic or proteomic studies, or for selection of DNA markers toward construction of a genetic linkage map.

To determine functional profiles of proteins in the predicted shrimp proteome, we decided to use only the matched ESTs from the 4 Penaeid shrimp species in the profile analysis. The ESTs were matched to the besthit proteins and existing annotation information for the proteins from either $D$. melanogaster or $C$. elegans to create the first level Gene Ontology (GO) classes. The 3 groups of shrimp ESTs were then individually analyzed for their gene ontology functional profiles (Figure 3).

The GO distribution profile of the group 1 ESTs of Penaeid shrimp (matching both fruit fly and nematode proteins), constituting 26\% (71,616 ESTs) of the EST data and best-matched with 4,201 fruit fly proteins gave the most of annotated functions (Figure 3, orange bars) [Additional file 4]. The group 2 ESTs (fruit fly proteinlike only) showed a lesser number of annotated functions, yet it uniquely harbored a notable function group called nutrient reservoir activity (Figure 3, pink bar, red arrow) [Additional file 5]. Proteins with house-keeping functions, such as ribosomal proteins, were found in these 2 groups. The group 3 ESTs of shrimp (matching only nematode proteins, Figure 3, green bar) showed the least number of annotated functions [Additional file 6]. Although only $1 \%$ of EST data were in this group, this amounted to 526 nematode proteins, which is not a negligible number. We are tempted to speculate that group 3 ESTs might correspond to ancient proteins that have been lost in insects during the course of evolution, but have been retained in shrimp. From the protein names in the 3 EST groups, we could identify over a thousand fruit fly proteins that lacked matching ESTs in shrimp or decapods, including complexin, hephaestus, ewg, dachshund and dynamin. It is too early to tell

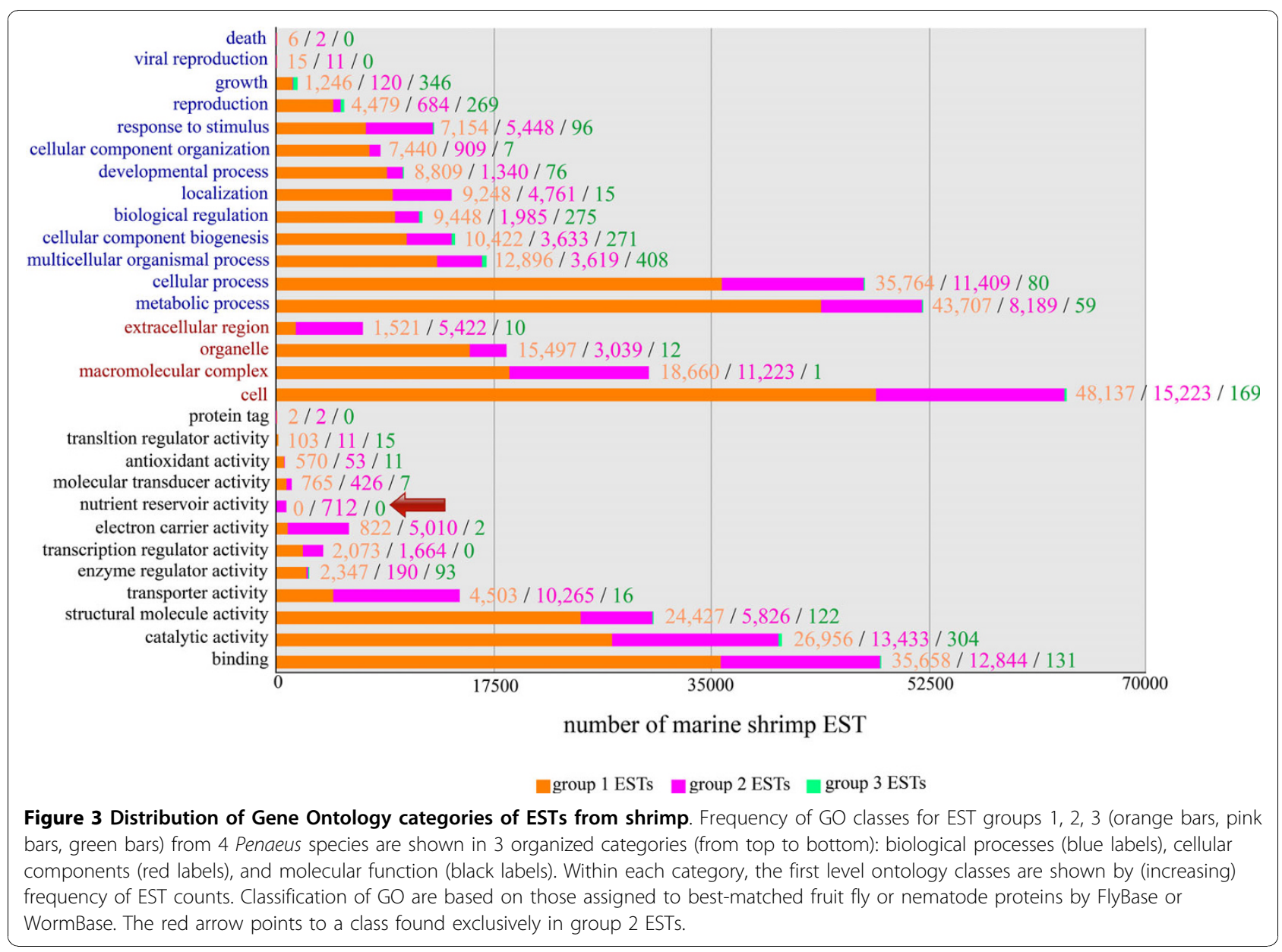




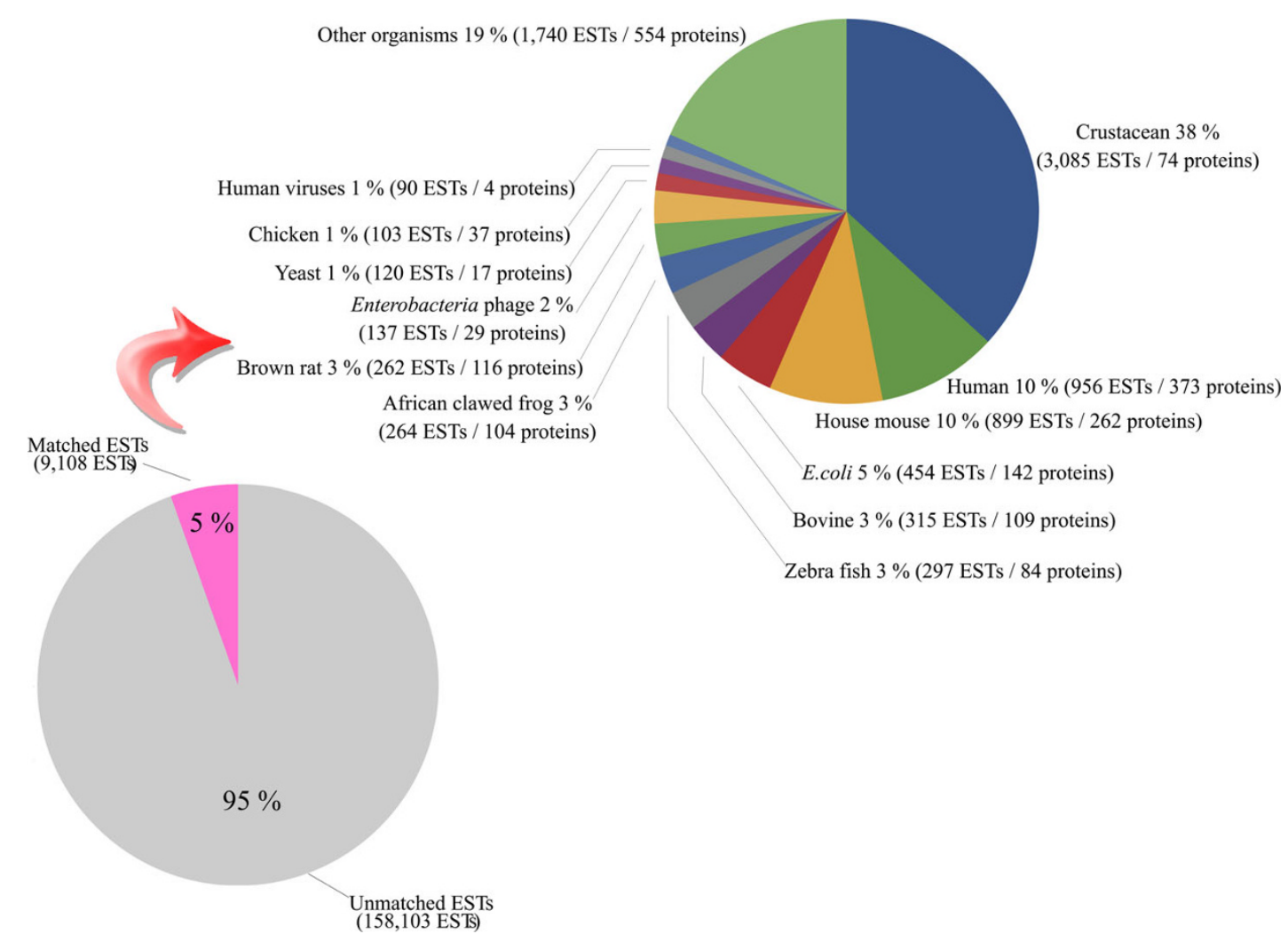

Figure 4 Distribution of unmatched shrimp ESTs, a portion of which matched protein sequences from other species. Around $61 \%$ of shrimp ESTs that did not match to fruit fly or nematode proteins were compared to protein sequences from UniProt using BLASTX and TBLASTN. Only 5\% matched protein sequences from other species. The data sector designated as crustacean encompassed several species.

whether shrimp actually lack these proteins, or whether their cDNAs simply have not been isolated and characterized so far.

In order to determine whether the $61 \%$ unmatched EST population combined from 4 shrimp species had any sequence similarity to proteins from other species [Additional file 7], they were compared with all protein sequences in the UniProt databases using BLASTX and TBLASTN. Only 5\% (9,108 ESTs) matched known proteins from other species (Figure 4) [Additional file 8]. The majority of newly-matched sequences were known crustacean protein sequences (38\%, multiple species). Matched proteins from other species included those from humans $(10 \%)$, the house mouse $(10 \%)$, the cow (3\%), zebra fish (3\%), the African clawed frog (3\%), the brown rat $(3 \%)$, bacteriophages $(2 \%)$, yeasts $(1 \%)$, human viruses (1\%), and other species (19\%). Of the $5 \%$ of ESTs matching $E$. coli sequences, some might be contaminating sequences from cloning vectors. The predominant portion of the set of unmatched shrimp ESTs might still include some less-conserved proteins that would be useful for further studies.

\section{Conclusion}

Our analysis shows the benefit of combining ESTs from related shrimp species to compensate for the small collection size of individual species and allow for the prediction of a conserved shrimp proteome model. Comparing EST sequences with whole-genome proteomes in model species allowed an assessment of the degree of coverage in existing EST collections for shrimp. Grouping of matching results provided evidence that predicted protein sets from shrimp and other crustaceans are more similar to those of an insect than a nematode. Furthermore, it revealed sub-populations of proteins similar to those common to both insect and nematode models, those present specifically in either model, or those present in neither. Slightly different profiles among the 3 matching EST groups were also observed from mapped GO functions. Our results suggest that conserved proteins in the 3 EST groups would be useful for transferring of annotation data from both model species to shrimp, for facilitating interpretations in microarray studies, for selection of cDNA clones to be used as genetic markers, and for further studies in 
shrimp proteins with particular functions or in particular groups.

\section{Additional material}

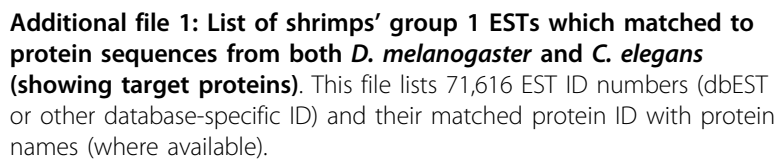

Additional file 2: List of shrimps' group 2 ESTs which matched to protein sequences from $D$. melanogaster only and their best-hit fruit fly protein ID. This file lists 31,517 EST ID numbers (dbEST or other database-specific ID) and their best hit proteins with protein names (where available).

Additional file 3: List of shrimps' group 3 ESTs which matched to $C$. elegans protein sequences (showing hit proteins). This file lists 2,194 EST ID numbers (dbEST or other database-specific ID) and their matched WormBase ID and names of $C$. elegans proteins (where available).

Additional file 4: List of shrimps' group 1 ESTs which matched to protein sequences from both $D$. melanogaster and C. elegans and GO function. This file lists 71,616 EST ID numbers (dbEST or other database-specific ID) and their first level GO function based on assignments to matched $D$. melanogaster proteins.

Additional file 5: List of shrimp-only ESTs which matched to $D$. melanogaster protein sequences and GO function (group 2 ESTs) This file lists 31,517 EST ID numbers (dbEST or other database-specific ID) and their first level GO function based on matched D. melanogaster proteins.

Additional file 6: List of shrimps' group 3 ESTs which matched to proteins from C. elegans and GO function. This file lists 2,194 EST ID numbers (dbEST or other database-specific ID) and their first level GO function based on matched C. elegans proteins.

Additional file 7: List of non-matched shrimp ESTs which did not matched to any D. melanogaster or C. elegans proteins. This file lists 167,211 EST ID not found similar to protein sequences in the 2 model species

Additional file 8: List of shrimps' group 4 ESTs which matched to proteins in UniProt database. This file lists 9,108 EST ID which did not find matching to proteins in the 2 model species but found matching to proteins from other species, with function and name of hit species.

\section{Acknowledgements}

This work was supported by National Center for Genetic Engineering and Biotechnology (BIOTEC), National Science and Technology Development Agency (NSTDA), Ministry of Science and Technology, Thailand. We thank BIOTEC for providing a high performance computational facility and the Faculty of Science, Mahidol University, for facility support. We thank Professor Prapon Wilairat and Professor T.W. Flegel for kindly reading and editing the manuscript. We also thank Dr. Pornpimol Rongnoparut and Dr. Saengchan Senapin for reading the manuscript and giving useful comments.

\section{Author details}

${ }^{1}$ Center of Excellence for Shrimp Molecular Biology and Biotechnology (CENTEX Shrimp), Faculty of Science, Mahidol University, Rama VI Road, Bangkok 10400, Thailand. 'National Center for Genetic Engineering and Biotechnology (BIOTEC), National Science and Technology Development Agency (NSTDA), Ministry of Science and Technology, Thailand Science Park, 113 Paholyothin Road, Tambon Khlong 1, Amphoe Khlong Luang, Pathum Thani 12120, Thailand. ${ }^{3}$ Department of Microbiology, Faculty of Science, Mahidol University, Rama VI Road, Bangkok 10400, Thailand. ${ }^{4}$ Department of Chemistry, Srinakharinwirot University, Sukhumvit 23 Rd., Bangkok 10110, Thailand.

\section{Authors' contributions}

$\mathrm{BS}, \mathrm{PP}$, and TS planned the project and interpreted the results. PL, UT, RK conducted the experiments. BS drafted the manuscript. All authors read and approved the final manuscript.

\section{Competing interests}

The authors declare that they have no competing interests.

Received: 15 July 2010 Accepted: 11 November 2010 Published: 11 November 2010

\section{References}

1. Flegel TW: Detection of major penaeid shrimp viruses in Asia, a historical perspective with emphasis on Thailand. Aquaculture 2006, 258:1-33.

2. Biao X, Kaijin Y: Shrimp farming in China: Operating characteristics, environmental impact and perspectives. Ocean \& Coastal Management 2007, 50:538-550.

3. Benson DA, Karsch-Mizrachi I, Lipman DJ, Ostell J, Sayers EW: GenBank. Nucleic Acids Res 2010, 38:D46-D51.

4. Colbourne JK, Singan VR, Gilbert DG: wFleaBase: the Daphnia genome database. BMC Bioinformatics 2005, 6:45.

5. Colbourne JK, Eads BD, Shaw J, Bohuski E, Bauer DJ, Andrews J: Sampling Daphnia's expressed genes: preservation, expansion and invention of crustacean genes with reference to insect genomes. BMC Genomics 2007, 8:217.

6. McTaggart SJ, Conlon C, Colbourne JK, Blaxter ML, Little TJ: The components of the Daphnia pulex immune system as revealed by complete genome sequencing. BMC Genomics 2009, 10:175.

7. Boguski MS, Lowe TM, Tolstoshev CM: dbEST-database for "expressed sequence tags". Nature Genet 1993, 4:332-3.

8. Tassanakajon A, Klinbunga S, Paunglarp N, Rimphanitchayakit V, Udomkit A, Jitrapakdee S, Sritunyalucksana K, Phongdara A, Pongsomboon S, Supungul P, Tang S, Kuphanumart K, Pichyangkura R, Lursinsap C: Penaeus monodon gene discovery project: The generation of an EST collection and establishment of a database. Gene 2006, 384:104-112.

9. Leu JH, Chang CC, Wu JL, Hsu CW, Hirono I, Aoki T, Juan HF, Lo CF, Kou GH, Huang HC: Comparative analysis of differentially expressed genes in normal and white spot syndrome virus infected Penaeus monodon. BMC Genomics 2007, 8:120.

10. Adams MD, Celniker SE, Holt RA, Evans CA, Gocayne JD, Amanatides PG, Scherer SE, Li PW, Hoskins RA, Galle RF, George RA, Lewis SE, Richards S, Ashburner M, Henderson SN, Sutton GG, Wortman JR, Yandell MD, Zhang Q, Chen LX, Brandon RC, Rogers YH, Blazej RG, Champe M, Pfeiffer BD, Wan KH, Doyle C, Baxter EG, Helt G, Nelson CR, Gabor GL, Abril JF, Agbayani A, An HJ, Andrews-Pfannkoch C, Baldwin D, Ballew RM, Basu A, Baxendale J, Bayraktaroglu L, Beasley EM, Beeson KY, Benos PV, Berman BP, Bhandari D, Bolshakov S, Borkova D, Botchan MR, Bouck J, Brokstein P, Brottier P, Burtis KC, Busam DA, Butler H, Cadieu E, Center A, Chandra I, Cherry JM, Cawley S, Dahlke C, Davenport LB, Davies P, de Pablos B, Delcher A, Deng Z, Mays AD, Dew I, Dietz SM, Dodson K, Doup LE, Downes M, Dugan-Rocha S, Dunkov BC, Dunn P, Durbin KJ, Evangelista CC, Ferraz C, Ferriera S, Fleischmann W, Fosler C, Gabrielian AE, Garg NS, Gelbart WM, Glasser K, Glodek A, Gong F, Gorrell JH, Gu Z, Guan P, Harris M, Harris NL, Harvey D, Heiman TJ, Hernandez JR, Houck J, Hostin D, Houston KA, Howland TJ, Wei MH, Ibegwam C, Jalali M, Kalush F, Karpen GH, Ke Z, Kennison JA, Ketchum KA, Kimmel BE, Kodira CD, Kraft C, Kravitz S, Kulp D, Lai Z, Lasko P, Lei Y, Levitsky AA, Li J, Li Z, Liang Y, Lin X, Liu X, Mattei B, Mclntosh TC, McLeod MP, McPherson D, Merkulov G, Milshina NV, Mobarry C, Morris J, Moshrefi A, Mount SM, Moy M, Murphy B, Murphy L, Muzny DM, Nelson DL, Nelson DR, Nelson KA, Nixon K, Nusskern DR, Pacleb JM, Palazzolo M, Pittman GS, Pan S, Pollard J, Puri V, Reese MG, Reinert K, Remington K, Saunders RD, Scheeler F, Shen H, Shue BC, Sidén-Kiamos I, Simpson M, Skupski MP, Smith T, Spier E, Spradling AC, Stapleton M, Strong R, Sun E, Svirskas R, Tector C, Turner R, Venter E, Wang AH, Wang X, Wang ZY, Wassarman DA, Weinstock GM, Weissenbach J, Williams SM, Woodage T, Worley KC, Wu D, Yang S, Yao QA, Ye J, Yeh RF, Zaveri JS, Zhan M, Zhang G, Zhao Q, Zheng L, Zheng XH, Zhong FN, Zhong W, Zhou X, Zhu S, Zhu X, Smith HO, Gibbs RA, Myers EW Rubin GM, Venter JC: The genome sequence of Drosophila melanogaster. Science 2000, 287:2185-95. 
11. Holt RA, Subramanian GM, Halpern A, Sutton GG, Charlab R, Nusskern DR, Wincker P, Clark AG, Ribeiro JM, Wides $R$, et al: The genome sequence of the malarial mosquito Anopheles gambiae. Science 2002, 298:129-149.

12. Nene V, Wortman JR, Lawson D, Haas B, Kodira C, Tu Z, Loftus B, Xi Z, Megy K, Grabherr M, Ren Q, et al: Genome sequence of Aedes aegypti, a major arbovirus vector. Science 2007, 316:1718-1723.

13. Tribolium Genome Sequencing Consortium: The genome of the model beetle and pest Tribolium castaneum. Nature 2008, 452:949-955.

14. C. elegans Sequencing Consortium: Genome sequence of the nematoe $C$. elegans: A platform for investigating biology. Science 1998, 282:2012-2018.

15. Stein LD, Bao Z, Blasiar D, Blumenthal T, Brent MR, Chen N, Chinwalla A, Clarke L, Clee C, Coghlan A, Coulson A, D'Eustachio P, Fitch DH, Fulton LA Fulton RE, Griffiths-Jones S, Harris TW, Hillier LW, Kamath R, Kuwabara PE, Mardis ER, Marra MA, Miner TL, Minx P, Mullikin JC, Plumb RW, Rogers J, Schein JE, Sohrmann M, Spieth J, Stajich JE, Wei C, Willey D, Wilson RK, Durbin R, Waterston RH: The genome sequence of Caenorhabditis briggsae: a platform for comparative genomics. PLoS Biol 2003, 1:E45.

16. Sea Urchin Genome Sequencing Consortium: The genome of the sea urchin Strongylocentrotus purpuratus. Science 2006, 314:941-952.

17. Adams MD, Kelley JM, Gocayne JD, Dubnick M, Polymeropoulos MH, Xiao H, Merril CR, Wu A, Olde B, Moreno RF, et al: Complementary DNA sequencing: expressed sequence tags and human genome project. Science 1991, 252:1651-6.

18. Amparyup P, Jitvaropas R, Pulsook N, Tassanakajon A: Molecular cloning, characterization and expression of a masquerade-like serine proteinase homologue from black tiger shrimp Penaeus monodon. Fish \& Shellfish Immunol 2007, 22:535-546.

19. Sritunyalucksana K, Wannapho W, Lo CF, Flegel TW: PmRab7 is a VP28binding protein involved in White Spot Syndrome Virus infection in shrimp. J Virol 2006, 80:10734-10742.

20. Leelatanawit R, Klinbunga S, Aoki T, Hirono I, Valyasevi R, Menasveta P. Suppression subtractive hybridization (SSH) for isolation and characterization of genes related to testicular development in the giant tiger shrimp Penaeus monodon. BMB Report 2008, 41:796-802.

21. Chotwiwatthanakun C, Ngopon J, Unajak S, Jitrapakdee S: The ribophorin I from Penaeus monodon shrimp: cDNA cloning, expression and phylogenetic analysis. Comparative Biochem Physiol part B 2008, 150:331-337.

22. Supungul P, Rimphanitchayakit V, Aoki T, Hirono I, Tassanakajon A: Molecular characterization and expression analysis of a c-type and two novel muramidase-deficient i-type lysozymes from Penaeus monodon. Fish \& Shellfish Immunol 2010, 28:490-498.

23. Clavero-Salas A, Sotelo-Mundo RR, Gollas-Galván T, Hernández-López J, Peregrino-Uriarte AB, Muhlia-Almazán A, Yepiz-Plascencia G: Transcriptome analysis of gills from the white shrimp Litopenaeus vannamei infected with White Spot Syndrome Virus. Fish \& Shellfish Immunol 2007, 23:459-472.

24. Robalino J, Almeida JS, McKillen D, Colglazier J, Trent HF, Chen YA, Peck MET, Browdy CL, Chapman RW, Warr GW, Gross PS: Insights into the immune transcriptome of the shrimp Litopenaeus vannamei: tissuespecific expression profiles and transcriptome responses to immune challenge. Physiol Genomics 2007, 29:44-56.

25. Altschul SF, Madden TL, Schäffer AA, Zhang J, Zhang Z, Miller W, Lipman DJ: Gapped BLAST and PSI-BLAST: a new generation of protein database search programs. Nucleic Acids Res 1997, 25:3389-3402.

26. Ashburner M, Ball CA, Blake JA, Botstein D, Butler H, Cherry JM, Davis AP, Dolinski K, Dwight SS, Eppig JT, Harris MA, Hill DP, Issel-Tarver L, Kasarskis A, Lewis S, Matese JC, Richardson JE, Ringwald M, Rubin GM, Sherlock G: Gene ontology: tool for the unification of biology. The Gene Ontology Consortium Nat Genet 2000, 25:25-9.

27. Drysdale RA, Crosby MA, The FlyBase Consortium: FlyBase: genes and gene models. Nucleic Acids Res 2005, 33:D390-D395.

28. Chen N, Harris TW, Antoshechkin I, Bastiani C, Bieri T, Blasiar D, Bradnam K, Canaran P, Chan J, Chen C-K, Chen WJ, Cunningham F, Davis P, Kenny E, Kishore R, Lawson D, Lee R, Muller H-M, Nakamura C, Pai S, Ozersky P, Petcherski A, Rogers A, Sabo A, Schwarz EM, Van Auken K, Wang Q, Durbin R, Spieth J, Sternberg PW, Stein LD: WormBase: a comprehensive data resource for Caenorhabditis biology and genomics. Nucleic Acids Res 2005, 33:D383-D389.
29. Hubbard T, Andrews D, Caccamo M, Cameron G, Chen Y, Clamp M, Clarke L, Coates G, Cox T, Cunningham F, Curwen V, Cutts T, Down T, Durbin R, Fernandez-Suarez XM, Gilbert J, Hammond M, Herrero J, Hotz H, Howe K, lyer V, Jekosch K, Kahari A, Kasprzyk A, Kneefe D, Keenan S, Kokocinsci F, London D, Longden I, McVicker G, Melsopp C, Meidl P, Potter S, Proctor G, Rae M, Rios D, Schuster M, Searle S, Severin J, Slater G, Smedley D, Smith J, Spooner W, Stabenau A, Stalker J, Storey R, Trevanion S, Ureta-Vidal A, Vogel J, White S, Woodwark C, Birney E: Ensembl. Nucleic Acids Res 2005, 33:D447-D453.

30. The UniProt Consortium: The Universal Protein Resources. Nucleic Acids Res 2008, 36:D190-D195.

31. Stajich JE, Bloch D, Boulez K, Brenner SE, Chervitz SA, Dagdigian C, Fuellen G, Gilbert JGR, Korf I, Lapp H, Lehvaslaiho H, Matsalla C, Mungall CJ, Osborne BI, Pocock MR, Schnattner P, Senger M, Stein LD, Stupka E, Wilkinson MD, Birney E: The Bioperl Toolkit: Perl Modules for the Life Sciences. Genome Res 2002, 12:1611-1618.

doi:10.1186/1756-0500-3-295

Cite this article as: Leekitcharoenphon et al:: Predicted sub-populations in a marine shrimp proteome as revealed by combined EST and CDNA data from multiple Penaeus species. BMC Research Notes 2010 3:295.

\section{Submit your next manuscript to BioMed Central and take full advantage of:}

- Convenient online submission

- Thorough peer review

- No space constraints or color figure charges

- Immediate publication on acceptance

- Inclusion in PubMed, CAS, Scopus and Google Scholar

- Research which is freely available for redistribution

Submit your manuscript at www.biomedcentral.com/submit
C) Biomed Central 